\title{
Déficits, câmbio e crescimento ${ }^{\dagger}$
}

Luiz Carlos Bresser-Pereira*

RESUMO - Hoje já existe um conjunto de pesquisas significativo mostrando que quanto menor for o déficit (ou maior o superávit) em conta corrente, maior é a taxa de crescimento do país. Esta mesma relação pode ser decomposta e dois estágios, de forma que quanto menor for o déficit (ou maior o superávit) em conta corrente, mais competitiva é a taxa de câmbio, e quanto mais competitiva a taxa de câmbio, maior a taxa de crescimento do país.

São muitos os economistas ortodoxos brasileiros, mas nenhum é tão sério e competente quanto o prof. Affonso Celso Pastore. Suas análises macroeconômicas são sempre bem estruturadas e bem argumentadas, e terminam quase sempre pela recomendação de maior austeridade fiscal - algo com o que concordo. Somos ambos contra déficits públicos que endividam irresponsavelmente o Estado. Por que não ter a mesma posição em relação a déficits em conta corrente que endividam irresponsavelmente a nação (as famílias, as empresas e o Estado somados)? Por que dois pesos e duas medidas? O prof. Pastore, em artigo no O Estado de S. Paulo (28/2/2010), tem uma explicação para esta contradição - para sua defesa de déficits em conta corrente e para a política cambial vigente. Ela reproduz a teoria que os países ricos e seus economistas sempre usaram em relação aos países em desenvolvimento: propor que incorram em déficit em conta corrente para assim obter "poupança externa" na forma de investimentos diretos ou de empréstimos que financiem aquele déficit. O pressuposto que o nome "poupança externa" sugere é que o déficit em conta corrente se somaria à poupança interna dos países, e, assim, sua taxa de investimento (que é decisiva para o desenvolvimento econômico) aumentaria. Entretanto, esta tese, ou a afirmação que "os países ricos em capital devem transferir seus capitais para os países pobres em capitais" é tão verdadeira quanto a de que a terra é plana... Parece ser verdadeira, mas é essencialmente falsa.

Quando um país decide aceitar essa proposta de "crescimento com poupança externa", a primeira consequência é a apreciação da taxa de câmbio. Em seguida, do lado da oferta, ocorre o aumento artificial dos salários, e, em consequência, o aumento do consumo interno. Dada a propensão marginal a poupar elevada existente nos países em desenvolvimento, o aumento do consumo e a correspondente redução da poupança interna

† Artigo publicado originalmente no jornal O Estado de S. Paulo, 07 Março de 2010.

* Doutor em economia, professor de economia da FGV-SP e Ex-Ministro da Fazenda. 
são grandes, de forma que diminui a poupança interna e a poupança externa em grande parte a substitui, ao invés de se constituir em um acréscimo à poupança interna. Do lado da demanda, o resultado é o mesmo: a apreciação da moeda provoca a diminuição das oportunidades de investimento lucrativo voltados para a exportação; caem os investimentos e, em termos keynesianos, cai a poupança interna. Mais amplamente, o endividamento externo provoca uma sucessão de três males: primeiro, temos uma elevada taxa de substituição da poupança interna pela externa, grande parte das entradas de capitais financiando o consumo ao invés do investimento; segundo, temos o aumento do endividamento externo que leva o país a uma condição de fragilidade externa e à política desastrosa do confidence building, a aceitar sem crítica as recomendações de nossos credores e concorrentes; e, terceiro, temos a crise de balanço de pagamentos.

Se os investimentos de empresas multinacionais (que são desejáveis se trouxerem tecnologia para o país) financiam déficit em conta corrente, eles têm o mesmo destino dos empréstimos. Mesmo que a empresa multinacional faça um investimento novo ao invés de apenas comprar uma empresa já existente, boa parte dos recursos entrados no país acaba indiretamente financiando o consumo através da valorização do câmbio. Isto não aconteceria se o investimento direto não financiasse déficit em conta corrente, mas se constituísse em recurso que o país usa para fazer seus investimentos e aplicações financeiras externas. É assim que age a China.

Argumenta Pastore que nossa taxa de poupança é insuficiente - menos da metade da mesma China. Não há dúvida sobre isto. O equívoco está em pensar linearmente que o problema se resolve com apelo à poupança externa. Hoje já existe um conjunto de pesquisas significativo mostrando que quanto menor for o déficit (ou maior o superávit) em conta corrente, maior é a taxa de crescimento do país. Esta mesma relação pode ser decomposta em dois estágios, de forma que quanto menor for o déficit (ou maior o superávit) em conta corrente, mais competitiva é a taxa de câmbio, e quanto mais competitiva a taxa de câmbio, maior a taxa de crescimento do país.

Como, então, aumentar a taxa de poupança do Brasil? É necessário que as famílias reduzam seu consumo de luxo e que o Estado reduza seus gastos administrativos ou burocráticos, ou, em outras palavras, que torne mais eficientes seus serviços sociais e seus serviços de segurança. Mas o mais importante para aumentar a poupança é administrar a taxa de câmbio para que ela se mantenha competitiva ao invés de cronicamente apreciada. É não aumentar artificialmente os salários, e, sim, garantir aos empresários boas expectativas de 
lucro ou, em outras palavras, boas oportunidades de investimento voltado para a exportação. Em um país que ainda tem mão-de-obra relativamente barata como o Brasil, se a taxa de câmbio for competitiva, todo o mercado externo estará aberto às suas empresas competentes. Quando a taxa de câmbio é sobreapreciada como é hoje a brasileira, de nada adianta ser eficiente.

O prof. Pastore afirma que "os críticos do atual regime cambial brasileiro" defendem uma taxa de câmbio "permanentemente mais depreciada". Não é isto que defendo, e sim uma taxa de câmbio de equilíbrio, ou seja, uma taxa de câmbio competitiva. Como defini-la? Se não fossemos vítimas da doença holandesa, a taxa de câmbio competitiva é aquela que equilibra intertemporalmente a conta corrente: é a taxa de câmbio de "equilíbrio corrente". Hoje, algo em torno de $\mathrm{R} \$ 2,00$ por dólar. Como, entretanto, temos uma leve mas real doença holandesa (grave é a dos países produtores de petróleo), a taxa de câmbio competitiva é a de "equilíbrio industrial" - ou seja, aquela taxa de câmbio que torna competitivas internacionalmente as empresas produtoras de bens e serviços comercializáveis que adotem tecnologia no estado da arte mundial. Hoje, algo provavelmente em torno de $\mathrm{R} \$ 2,40$ por dólar.

Para manter a taxa de câmbio relativamente estável nesse nível é preciso administrála. Sabemos que a taxa de câmbio dos países em desenvolvimento não é bem controlada pelo mercado, não flutua docemente em torno do equilíbrio corrente, como pretendem os ortodoxos. Nem é simplesmente volátil em torno desse equilíbrio, como supõem os keynesianos. Na verdade, se deixada completamente livre, ela tende estruturalmente à sobreapreciação, não sendo o mercado, mas as crises de balanço de pagamentos, as paradas súbitas, que a "controlam”. Quando ocorre a crise, há uma violenta depreciação, mas, em seguida, passam a operar as causas de apreciação. Entre elas, temos, em primeiro lugar, a doença holandesa, que puxa a taxa de câmbio do equilíbrio industrial para o corrente; em seguida, a política de crescimento com poupança externa, as entradas de capitais especulativos e o populismo cambial que levam o país sucessivamente ao déficit em conta corrente, à substituição da poupança interna pela externa, ao endividamento externo excessivo, ao confidence building, e, afinal, a nova crise.

O prof. Pastore está ciente dos perigos dos déficits em conta corrente. Diz-nos ele: "Os déficits nas contas correntes muito elevados contêm a semente de sua própria destruição ao exigirem, depois de algum tempo, a depreciação do câmbio real de equilíbrio para financiar os encargos de um passivo externo líquido mais elevado.” Por que, então, a contradição de começar o artigo defendendo o "crescimento com poupança externa"? A explicação está nas 
duas crenças equivocadas que acabei de criticar: a crença que déficits em conta corrente valham à pena porque aumentariam significativamente os investimentos; e a crença que o mercado tende a manter a taxa de câmbio no equilíbrio desejado, não precisando ser administrada.

$\mathrm{Na}$ verdade, não basta controlar a taxa de inflação, é preciso também administrar a taxa câmbio de forma a neutralizar a tendência à sua sobreapreciação. Não é conveniente definir uma meta - é preferível pensá-la em termos de uma faixa - mas é fundamental que se garanta às empresas sua manutenção nesse nível. O desenvolvimento econômico brasileiro depende criticamente da existência de demanda - de oportunidades de investimento. No lado da oferta, o único ponto de estrangulamento de curto prazo é o da infraestrutura - e este problema exige um esforço redobrado do governo e das empresas. Realizado esse esforço e garantida uma taxa de câmbio competitiva - no nível do equilíbrio industrial - o Brasil poderá crescer nos próximos anos a uma taxa média em torno de 7\% ano, ao invés dos 3,5\% que, em média, a atual taxa de câmbio permite, em meio a crises recorrentes. Os países asiáticos dinâmicos crescem a taxas muito superiores à brasileira porque aprenderam a administrar sua taxa de câmbio. Está na hora de nós fazermos o mesmo. 